\title{
Carrying Capacity Assessment for Coastal Tourism and its Implication for Geographical Education
}

\author{
Ahyuni $^{1)}$ and Hamdi Nur ${ }^{2)}$ \\ 1) Departement of Geografi, Universitas Negeri Padang \\ 2) Departement of Urban and Regional Planning, Universitas Bung Hatta \\ e-mail : hamdinur@yahoo.com e-mail : ahyuniaziz@gmail.com
}

\begin{abstract}
Carrying capacity of coastal tourism need to be reviewed from the multiple aspect of ecology, physical, political and economic as well as socio-cultural. Then various indicators need to be formulated to make an assessment of the impact of coastal tourism development. The cases of coastal tourism could be an interesting topic to integrate the subject matter of geography. In this paper the framework of that carrying capacity is applied to Mandeh coastal tourism development in West Sumatra.
\end{abstract}

\section{Keywords: Coastal Carrying Capacity, Impact of Development, Indicator for Assessment}

\section{Introduction}

Coastal tourism is expected to become a sector of destinations to attract tourists in the future. UNWTO's Tourism 2020 Vision forecasts that international arrivals are expected to reach nearly 1.6 billion by the year 2020. Of these worldwide arrivals in 2020,1.2 billion will be intraregional and 378 million will be long-haul travellers. We can see from graphic below, tourist growth forecast for East Asia and Pasific more higher then others region. Furthermore, UNWTO statistics show that 12 of the 15 world's top destination countries in 2000 were countries with coastline (UNEP, 2009). The coastal tourism sector of the world is increasingly growing in importance with regard to its magnitude and contribution to national economies as well as to the wellbeing of local communities.

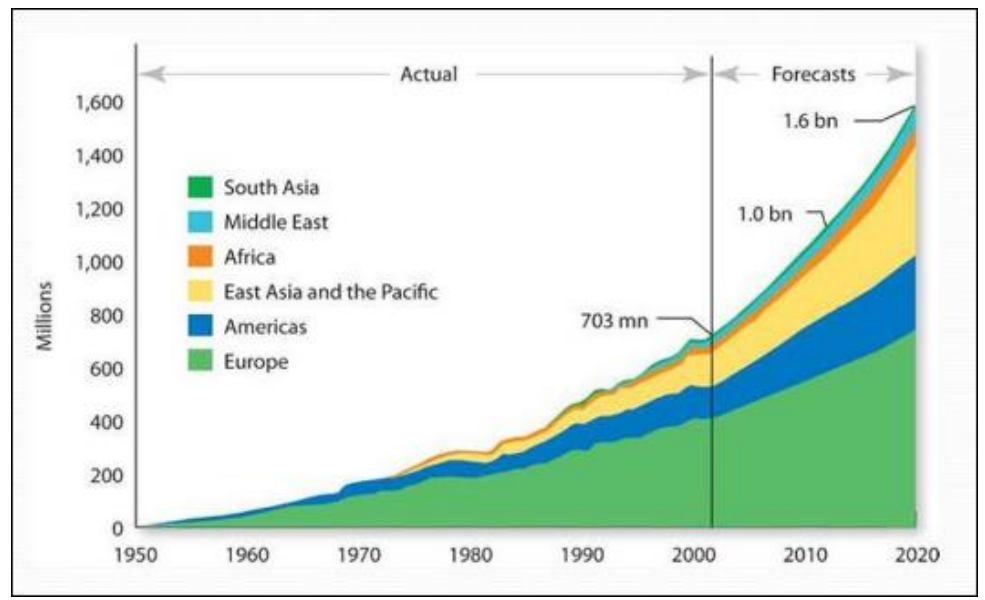

Figure 1. International Tourist Arrivals and Trends, 1950-2020 (Source: World Tourism Organization (2009) 
However, the development of coastal areas for tourism in addition to bringing benefits also gives rises the possibility of adverse physical environmental impacts such as: loss of marine resources due to destruction of coral reefs, pollution of marine and freshwater resources, soil degradation and loss of land resources, erosion, loss of public access, or natural hazards and loss of wealth biodiversity. Especially on coastal areas, the development of tourism destinations for tourist desire and satisfaction by developed buildings for accomodation and leasure might result in downgrading of the coastal landscape scenic beauty. On the other hand, commercialization of tourism destination can cause social disruption or social conflict. Economic inequality between locals resident or between locals and tourist might occur due to the development of new economic activities. Cultural dan behaviour differences might be cause them fail to respect local customs and moral values and trigger cultural clash.

Coastal tourism development need to pay attention to tourist demand. Based on studies that have been done, most important environmental factor considered by coastal tourists is the quality of natural environment. Artificial factors likes accessibility to destination or access to information is not a very important priority. As an example, based on studies carried out in Germany on a sample of 7,872 conducted in 2002, the most important environmental factors listed by order of importance were as follows (ECOTRANS/F.U.R. Reiseanalyse (2002): Clean beaches and water (64.5\%), No rubbish in the resort or in the surrounding area $(59.1 \%)$, No urbanisation of rural areas $(50.0 \%)$, Good nature protection in the holiday destination $(51.0 \%)$, No noise pollution from traffic or discothèques $(45.8 \%)$, Minimal traffic and good public transport in the destination (35.1\%), Possibility of reaching the destination easily by bus or train (29.0\%), Environmentally-friendly accommodation (41.8\%), Finding environmentally-friendly accommodation in tour operator or travel agents' catalogues $(18.7 \%)$ and, Easy access to information on offers with verified environmentally-friendly accommodation $(14.2 \%)$

\section{How to Define Tourism Carrying Capacity}

Carrying capacity is defined as the growth limits an area can accommodate without violating environmental capacity goals. It is a tool for sustainable development. The impact of tourism development especially for sensitive area for changing pressure like mostly coastal area will face the question about such topic. In the study of tourism, the first reference conducted by Sumner in 1936 which stated that the park is not possible to accommodate the unlimited number of visitors. Initial topic on the carrying capacity of tourist areas emphasizes the biological aspects. The concept of tourism carrying capacity as suggested by James and Ripley (1963) simply define as biological and physical limits of land to support tourism activities. It means that the concept of carrying capacity confine only on aspects of natural or artificial environment ability to support tourism activities without causing significant degradation of nature.

In the 1960s, began to note the social aspect of carrying capacity that is assessing a change of uses that cause changes in recreational experiences offered by an area different from the initial conditions that attract visitors. The concept of carrying capacity of the environment is thus not only focus on restrictions on the number of visitors that can be accommodated without causing environmental degradation but also associated with a decrease in visitor satisfaction. So also studied is the dimension of the impact on varied user of tourism areas. Another aspect which was later analyzed is the social acceptance of the local people.

Tourism carrying capacity as suggested by Lime and Stankey (1971) and Clark (1978) is more precisely defined as the level, type or character of the use of a particular area for recreation that can be supported at a certain time without causing deterioration of the environment physically and can maximize user satisfaction. Maintaining the character or the aesthetic quality and biotic wealth is important to provide maximum satisfaction for visitors. Tourist experience relied on the character of the environment such as its aesthetics, culture, vegetation and wildlife. So the concept of aesthetic recreational carrying capacity needs to be introduced as the level of development and use beyond which measurable decreases in satisfaction occur (this can be called psychological carrying capacity). And then, biotic carrying capacity as the level of 
development and use beyond the area capacity to a sustained high level of satisfaction becomes impaired due to damage to the natural site. Physical carrying capacity as the main concept of tourism analysis thus involves several things. First, the physical limitations of tourism activity in an area in terms of number of visitors, many accommodations that do not adversely affect the natural environment. Second, restrictions to development so that the satisfaction or psychological reception of visitors is maintained. Third, the social carrying capacity acceptance of the host people concerning the amount of tourist activities that can be tolerated in order not to disrupt their daily lives.

The carrying capacity is determined based on the limit or threshold that is established as an indicator of whether the development of tourism activities are still within the limits of sustainability. Indicators can be divided into objective limits (e.g., such as the environmental carrying capacity of beaches without causing environmental pollution or tourist accommodation by considering the availability of water resources clean) and subjective limit (e.g., the percentage of tourists and residents that has exceeded the threshold, causing a downgrading of the resort). There are three approaches to carrying capacity assessment to determine the sustainability limits (Jurado, 2012).

1. Carrying Capacity based on resources, the aim is to protect resources based on measurable limits of natural and cultural resources of destination.

2. Carrying capacity based on developer's perspectives, in this model, limits are dynamic, and changes will depend on how the destination adapts to new situation, for example, increasing carrying capacity with infrastructure or renewing products. The limits depend on tourism sector, segments of destination, and its resources. If growth does not exist, an indication that the limits of carryinging capacity has been reached and new tourism products are needed.

3. Carrying Capacity based on community based, focus on selection of limits through the participation of share capital via a process of social negotiation. The objective is to satisfy both tourist and residents.

The first point above is the objective limits measurable technically such as limitation of development based on consideration of the morphological characteristics of the beach, the carrying capacity of the land, change vulnerability travel to biodiversity of flora and fauna coastal, or availability of water determines the limit of lodgings for resident and tourist and carrying activities beaches. While the second and third point are limits based on subjective criteria which although can be measured quantitatively, but based on the subjective judgment of the community, user or policy makers. Subjective indicators can be known through interviews or questionnaire surveys. Coastal Tourism Assessment of carrying capacity to achieve sustainable development can be seen from some aspects, as follows (UNEP, 1999):

1. Ecological Carrying Capacity: At its simplest, this is a measure of the population that an ecosystem can sustain.

2. Physical Carrying Capacity: This is a measure of the spatial limitations of an area and is often expressed as the number of units that an area can physically accommodate. The physical carrying capacity is directly related to the infrastructure present in the area, for example, the number of available parking areas in terms of car units, etc. The physical carrying capacity also refers to the natural resources that are available and compatible with tourism development. It will be expressed in terms of: drinking water capacity, waste

water treatment capacity, renewable energy production capacity, solid waste treatment capacity, etc.

3. Socio-Cultural Carrying Capacity: The social carrying capacity focuses on residents' and visitors' perception of crowding.

4. Political and Economic Carrying Capacity: This is the organizational ability of a destination to coordinate and direct local tourism management through a sustainable pathway and integrating international directives. It seeks also to define the extent to which an area can be altered before the economic activities that occur in the area are adversely affected. It can be seen as a measure of how 
tourism, both positively or negatively, can affect other economies present in the area. It, therefore, attempts to measure changes in economic terms.

\section{Construction of Coastal Tourism Carrying Capacity Indicator}

Based on consideration of multiple dimension of coastal tourism carrying capacity, then relationship between approach, aspects, and indicators of limits or thresholds of carrying capacity can be constructed. In the following matrix is also outlined the possible impact when the limits of the indicator exceeded.

\begin{tabular}{|l|l|l|l|}
\hline $\begin{array}{c}\text { Approach of } \\
\text { carrying } \\
\text { capacity }\end{array}$ & $\begin{array}{c}|c| \\
\text { Aspect of } \\
\text { carrying } \\
\text { capacity }\end{array}$ & Indicator of limit or threshold & \multicolumn{1}{c|}{ Possibility impact } \\
\cline { 2 - 4 } $\begin{array}{l}\text { Based on } \\
\text { natural } \\
\text { resourced }\end{array}$ & Physical & $\begin{array}{l}\text { Lotal population and tourists } \\
\text { morphodynamics; Water health } \\
\text { index; Carrying capacity of } \\
\text { tourist } \\
\text { Accommodation; etc. }\end{array}$ & $\begin{array}{l}\text { loss of wealth biodiversity } \\
\text { character; destruction of } \\
\text { coral reefs; pollution of marine an } \\
\text { d freshwater resources; soil degra } \\
\text { dation; loss of land resources; ero } \\
\text { sion; natural hazards. }\end{array}$ \\
\hline $\begin{array}{l}\text { Based on } \\
\text { developer's } \\
\text { perspective }\end{array}$ & Political and & $\begin{array}{l}\text { Coastal carrying capacity to } \\
\text { induce growth; type of tourism } \\
\text { (mass tourism/special interest } \\
\text { tourism); limits of economic } \\
\text { activity to avoid inequality. }\end{array}$ & $\begin{array}{l}\text { Growth by tourism new product; } \\
\text { impact of mass tourism or } \\
\text { clustered exclusive tourism; } \\
\text { inequality; social disruption or } \\
\text { social conflict. }\end{array}$ \\
\hline $\begin{array}{l}\text { Based on } \\
\text { community } \\
\text { perspective }\end{array}$ & Socio-cultural & $\begin{array}{l}\text { Total population and tourist } \\
\text { allowed based on perception of } \\
\text { local resident; type of tourist } \\
\text { allowed or restricted }\end{array}$ & $\begin{array}{l}\text { trigger cultural clash; degrading } \\
\text { social values and norms }\end{array}$ \\
\hline
\end{tabular}

\section{Applying of Assessment in The Mandeh Tourism Destination}

Mandeh region is a bay which covered by row of small islands on the circular position, as if the sea lake. It made a relatively calm sea waters and are rich in coral reefs and mangrove forests are still preserved. As quiet beach with covered small islands in front of beaches and hills along the coastline that makes this region has a beatiful unique landscape that has great potential as an destination of coastal tourism. Mandeh is located on the western coast of West Sumatra province at regency of Pesisir Selatan. Region can be reached by road from Padang as province capital City with a distance of $\pm 60 \mathrm{Km}$. Besides by road, Mandeh can be reached via sea transport. Mandeh region has been included in the National Tourism Development Master Plan as emerging strategic coastal tourism destination in Indonesia. This area has very high potential for coastal tourism. Departement of tourism has been planned this area to become a Special Economic Zone (Kawasan Ekonomi Khusus).

This region has the potential of coral reefs, mangrove, sea grass area, and biodiversity area. There are several small islands in the region such as Cubadak, Marak, Pagang. Villages dispersed in the region is potential for rural tourism and culinary tourism. Mandeh Region topography can be classified into flat, hilly and mountainous. Flat to gently sloping land scattered in the coastal area which is a narrow plateau that is directly adjacent to the hills and the sea. The area with the topography mountainous and dominate the region plans around $77.4 \%$ of the land area Mandeh region. The beach on the bay in a relatively without abrasion due to protected by islands in the front of coast so coral reefs and fairly thick mangrove growths. In the upstream area there are many waterfalls located in the midst of tropical rain forest. The coastal plain consists of the coastal plain and beach ridge. Rock constituent dominated by alluvium, marsh sediment, and on some 
place there are remnants of pumice tuff. In some places there is a swamp/marsh that is located behind the beach ridge.

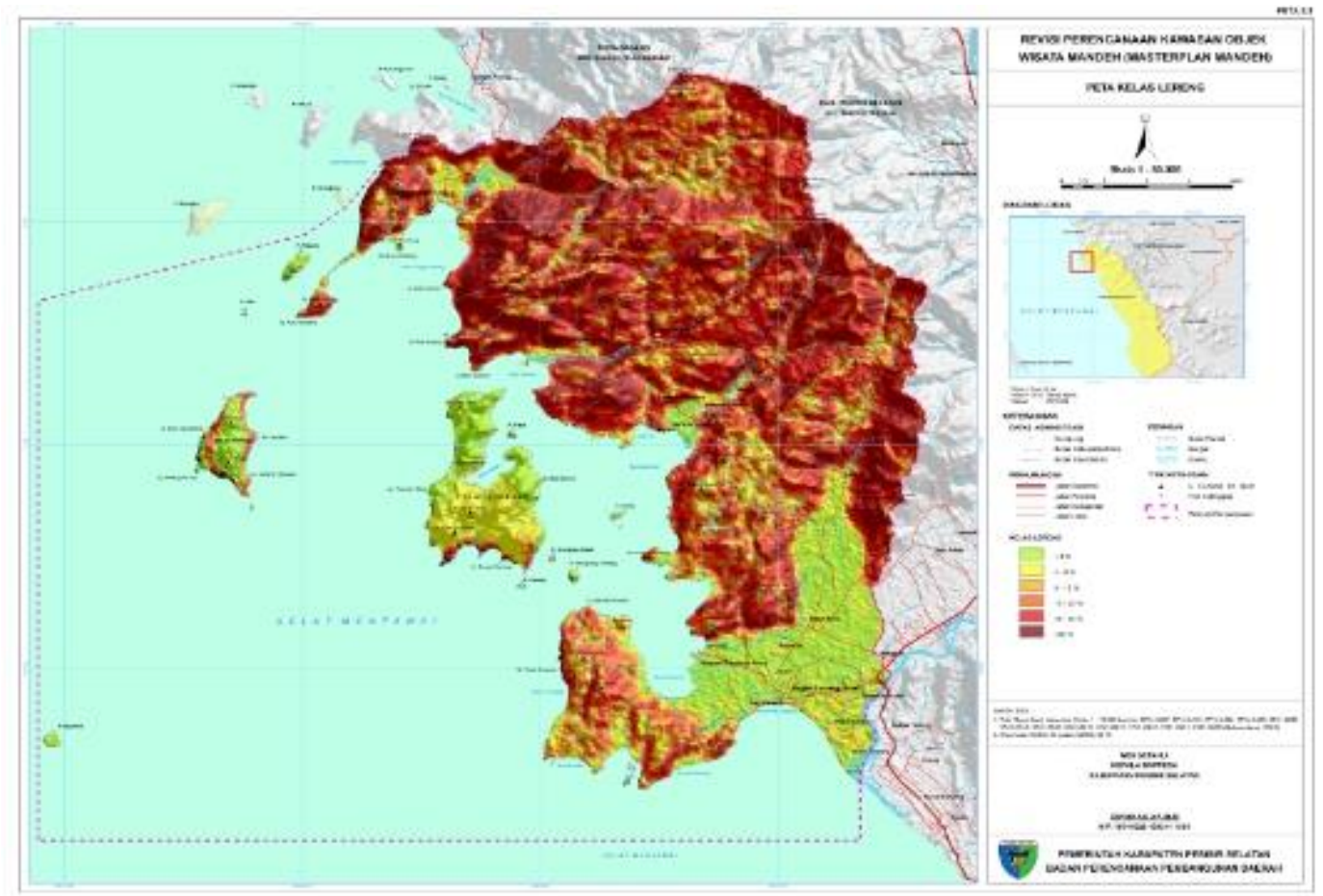

Figure 2. Relief of Mandeh Region

Some current issues involved sustainable development related of Mandeh Region successfully compiled based on field surveys and collected information in the mass media is as follow:

1. Opening road access along the coast will cause environmental disturbance because of the mass tourism that will develop will lead to environmental degradation. This will invite more visitors from middle and lower class segment. The behaviour of this type of tourist will cause litter pollution and water pollution in the wide areas.

2. With hilly and swampy coastal plain morphology in Mandeh region, the carrying capacity of the physical environment relatively low to support tourism activities. Swampy plain areas and steep hills are not suitable to support large-scale tourist accommodation because it can cause pollution of marine and fresh water resources, erosion and landslides.

3. Development of buildings along the coast will blocking the view to the sea so downgraded the aesthetic value of the coastal.

4. Large scale investment or artificial development such as resort and large scale facilities as wished by investor and government official can cause significant gaps and injustice for the people. Land aquisition by investor or land speculator might lead to impoverishment of local people.

5. exclusive tourism zone on a small island like that ever happen to cause segregation and loss of public access. This precedent should no longer occur.

6. Boating tour that has been growing rapidly has invited many entrepreneurs so as to might produce a conflict between them.

7. Ecotourism activity such as visit waterfalls are feared to disturb nature with vandalism and behavior not in accordance with the norms of society.

8. There should be a special zoning to protect the ecosystem that many turtle nesting in this area. 
9. To develop Mandeh region, it is necessary to distinguish between mass tourism and special interest tourism zone so that the zone is accordance with its physical character.

Based on the issues, some assessment indicators that need to be considered in the development of sustainable Mandeh region is as follows:

1. Ecological carrying capacity. The important issues in this aspect is the soil erosion that pollutes the waters caused by of road construction and disturbing of turtle nesting on the beach. Pollution by tourist activity will indirectly pollute waters. Therefore, the threshold number of tourists needs to be calculated. Indicator assessment required is the possibility of soil erosion; limited or free zone for preservation area, and threshold of tourist.

2. Physical carrying capacity. The important issues in this aspect is vulnerability of environment. The carrying capacity of the physical environment relatively low to support tourism activities. Indicator assessment required is land capacity, water health index, carrying capacity of tourism accomodation and facilities.

3. Political and economic carrying capacity. The important issues in this aspect is economic injustice and inequality caused by large investation in areas and social conflict among locals caused by bussiness competition. Indicator assessment required is measurement of equitable development.

4. Socio-cultural carrying capacity. The important issues in this aspect is the feared disturbing nature with vandalism and behavior not in accordance with the norms of society. Indicator assessment is restricted and allowed tourist behaviour.

The conclusion that can be drawn from the case of Mandeh tourism development is that very necessary to make assessment of the ecological and physical carrying capacity of vulnerable coastal environment. But on the other hand, it is also important to assess both behavioral and economics impact. Mass tourism as a market segment should not degrade the quality of the environment by theirs usually not care to environment behaviour. The economic activity generated in tourist areas should estimate the impact on inequality and social conflict.

\section{Conclusion}

Assessing impact of the development of the tourism coastal region could be an interesting case in integrated geography education that is various aspects of the teaching material in physical geography, human geography or economic geography can be used in understanding and finding solutions for the development of tourism. The introduction of assessment indicators can be an entry point for integrating geography subject matter. Concepts such as land capacity, carrying capacity, environment index, landscape character, human behavior can be combined to explain the phenomena of development.

\section{Reference}

Jurado, E. Navarro, et al. (2012). Carrying Capacity Assessment For Tourist Destinations. Methodology For The Creation Of Synthetic Indicators Applied In a Coastal Area. Tourism Management. 33: $1337-1346$

United Nations Environment Programme (UNEP). (2009). Sustainable Coastal TourismAn Integrated Planning And Management Approach. Priority Actions Programme Regional Activity Centre (PAP/RAC)

Lal Mukherjee, A. (2013). Impact of Tourism in Coastal Areas: Need of Sustainable TOURISM strategy.

ECOTRANS/F.U.R. (2002). German tourists expect environmental quality, press release, March 2002 announcing selected of F.U.R (Forschungsgruppe Urlaub und Reisen) and ECOTRANS, (Travel Analysis 2002), a comprehensive survey of nearly 8000 German tourist. source: http://www.coastlearn.org/lt/tourism/con_environment.html

Paul, W., and W. Hamilton. (2000). Hazmat. In GIS in schools, eds. R. Audet and G. Ludwig, pp. 13-21. Redlands, California: ESRI Press. 
Patterson TC. (2007). Google Earth as a (not just) geography education tool. Journal of Geography. 106:145152.

Queen, A. M., H. Easterling, and V. Connors. (1998). Teaching young researchers GIS: From wetlands to the Web. Geo Info Systems March: 38-41.

Ramirez, M. (1996). A driving force in technology education: Geographic information systems (GIS). TechTrends. 41: 34-36

Read JM. (2010). Teaching Introductory Geographic Information Systems through Problem-based Learning and Public Scholarship. Journal of Geography in Higher Education. 34:379-399

Songer LC. (2010). Using Web-Based GIS in Introductory Human Geography. Journal of Geography in Higher Education. 34:401-417.

Slater, T. F., B. P. Beaudrie, and R. L. Fixen. (1998). Implementing K-12 hypermediated earth system science activities based on World-Wide Web resources. Journal of Geoscience Education 46(2):149-153

Wilds, R., and D. Martin. (2005). Urban safety program. http://maps.culma.wayne.edu/info.htm

\author{
Ahyuni \\ Born in Batusangkar, West Sumatra, Indonesia. Master graduate of Andalas University. Active as a lecturer \\ in Geography of Universitas Negeri Padang, Indonesia
}

Hamdi Nur

Lecturer in Departement of Urban and Regional Planning, Universitas Bung Hatta 